\title{
P2P LENDING: COMPLEMENT OR SUBSTITUTE TO SMALL BANK
}

\author{
Dewi Tamara, Asnan Furinto, Andreas Hakim, Djury Santosa \\ Binus Business School, Binus University Jakarta,Indonesia \\ Email: dtamara@binus.edu, afurinto@binus.edu, andreas.hakim88@gmail.com, \\ djury.pme@gmail.com
}

\begin{abstract}
Rapid P2P lending growth in Indonesia is expected to bring new opportunities as well as risk to the traditional financial sector. Meanwhile, covid-19 pandemic have also brought many changes to the financial landscapes. In this current pandemic situations, not many studies have been conducted about the impact of P2P especially on small bank loans, which is the type of bank that will be the first to feel the disruption in performance, if any, as well as comparing the impact between pre pandemic and during the pandemic period. Thus, this paper aims to analyze and compare the effect of P2P lending growth on the growth of small bank loans, which consists of 56 banks as of June 2021, both before (January 2019-March 2020) and during the pandemic (April 2020-June 2021). We believe focusing the research on small banks is important because these are the incumbent players in the financial sector that are expected to be the most impacted by the arrival of the P2P lending business and the pandemic situation. This research used the quantitative approach. The analysis was carried out in stages using monthly secondary panel data obtained from OJK and BPS with multiple regression analysis. The variables we used are small bank loan growth as the dependent variable, and P2P loan growth, inflation, and money supply as the dependent variables. First we analyzed the data before the pandemic, then we analyzed after the pandemic data and compared both results. Results of this study showed that P2P lending did not have a significant impact on small bank's ability to disburse loans before the pandemic. However, our subsequent analysis regarding data during the pandemic showed that P2P lending has a significant positive impact on small bank loans growth, and gave evidence of $\mathrm{P} 2 \mathrm{P}$ complementary effect to small banks. Both results suggest that initially before the pandemic P2P main customer is the unbanked population that cannot have access to banks, then when the pandemic occurs, borrowers that have access to small banks also consider to use $\mathrm{P} 2 \mathrm{P}$ as their additional financing source.
\end{abstract}

Keywords: Inflation; Loan; Money Supply; P2P; Pandemic; Small Bank

Received: 2021-10-22; Accepted: 2021-11-05; Published: 2021-11-20

\begin{tabular}{ll}
\hline How to cite: & Tamara, D., Furinto, A., Hakim, A., Santosa, D., (2021) P2p Lending: Complement or Substitute To \\
& Small Bank, Syntax Idea, 3(10), https:// doi.org/10.36418/syntax-idea.v3i11.1570 \\
E-ISSN: & 2684-883X \\
Published by: & Ridwan Institute
\end{tabular}




\section{Introduction}

$\mathrm{P} 2 \mathrm{P}$ lending $(\mathrm{P} 2 \mathrm{P})$ is a practice where businesses/individuals who want to borrow money are met with businesses/individuals who have surplus money to be lent without involvement of traditional banks. In its implementation through various online platforms, P2P can also be described as a marketplace for lending activities which bring together borrower and lender. P2P in Indonesia itself has experienced substantial growth in recent years. For the period of December 2020 alone, its cumulative disbursement of loan has risen by $91,3 \%$ yoy (Keuangan, 2016) although the regulations and policies to keep these businesses in check have not matured enough (Suryono et al., 2019).

With its more simplified process in loan disbursement and easier access than traditional banks, $\mathrm{P} 2 \mathrm{P}$ has been hailed to have a disruptive effect on the current financial landscape especially in the banking sector. At the same time, P2P can also be seen as a solution for those who cannot be served by traditional banks (Tripathi et al., 2021).

Thus, we aim to analyze the impact of P2P loans on loans disbursed by small banks. We believe this research is important because it may provide useful insights for government as well as financial institutions about how to deal with the rapid growth of P2P, about where every player should position themselves, and ultimately what direction they must take to stay relevant in this rapidly changing environment. We will also divide the analysis to before and during covid-19 pandemic because we believe the pandemic has brought many changes that require its own analysis (Andini, 2017)

According to (Zhang et al., 2019) in their study claimed that in China, as P2P getting bigger, it had a negative effect on domestic bank loans. Almost similarly, (Herdinata \& Kohardinata, 2019) found that the growth of P2P in Indonesia has a significant impact on bank loans for the MSME segment. However, given the current pandemic situations, not many studies have been conducted about the impact of P2P especially on small bank loans, which is the type of bank that will be the first to feel the disruption in performance, if any (Yudaruddin, 2010).

Therefore, our study will find whether growth of P2P loans have a significant impact on small bank loans before and during the pandemic. We will use a quantitative method with panel data regression to test this hypothesis.

In the next section, we present literature reviews related to our study. In section 3 we describe our analysis methods and the datasets we used. In section 4 we present the results. Section 5 will discuss the results and compare our findings with those in the literature. Lastly, in section 6 we state our conclusions and suggest possible topics for future research.

\section{Research Methods}

This research was carried out using monthly panel data from January 2019 to May 2021. The data used in this research was secondary data as follows

1. Small bank loans growth (\%) obtained from the Financial Services Authority (OJK)'s Bank Publication Report 
2. P2P loans growth (\%) obtained from the Financial Services Authority (OJK)'s Fintech Lending Statistic Report

3. Both inflation (\%) and money supply growth (\%) obtained from Statistical Central Bureau (BPS)

4. We used multiple linear regression analysis to conclude if there is a significant relationship between the dependent and independent variables with $95 \%$ confidence level.

Table 2

Data Description

\begin{tabular}{|c|c|c|c|c|c|c|c|c|}
\hline \multirow[t]{2}{*}{ Indicators } & \multicolumn{4}{|c|}{ before pandemic } & \multicolumn{4}{|c|}{ during pandemic } \\
\hline & $\Delta \mathrm{SB}$ & $\Delta \mathbf{P} 2 \mathbf{P}$ & $\Delta \mathbf{M} 2$ & INF & $\Delta \mathrm{SB}$ & $\Delta \mathbf{P} 2 \mathbf{P}$ & $\Delta \mathbf{M} 2$ & INF \\
\hline means & $\begin{array}{c}0.658 \\
8\end{array}$ & 6.2666 & 0.6368 & 0.2572 & -0.003 & 2.9241 & 0.6267 & 0.1285 \\
\hline stand. & 2.309 & 3.3372 & 0.8415 & 0.24494 & 2.0662 & 5.9750 & 1.73397 & 0.14986 \\
\hline Deviation & 1 & 2 & 5 & & 6 & 9 & & \\
\hline $\min$ & -6.53 & 1.19 & -1.47 & -0.27 & -5.91 & -8.53 & -3.14 & -0.1 \\
\hline $\max$ & 6.97 & 10.92 & 1.98 & 0.68 & 6.8 & 12.28 & 3.69 & 0.45 \\
\hline Observation & \multicolumn{4}{|c|}{634} & \multicolumn{4}{|c|}{719} \\
\hline
\end{tabular}

Source: researcher analysis

From the table we can see that there is a drop of mean growth in both small bank loans and P2P loans during the pandemic.

Inflation data that we take from www. bi.go.id shows that before the pandemic from January 2019 to March 2020, the lowest was in March 2019 with an inflation rate of $2.48 \%$, and the highest was in August 2019 at 3.49\% with an average of 3\%. and during the pandemic that lasted from april 2020 to may 2021, the lowest inflation rate was at the level of 1.32\% recorded in August 2020, and the highest was in april 2020 at the level of $2.67 \%$, with an average figure during the pandemic of $1.65 \%$ (Firdaus et al., 2020).

Money supply (M2) from time to time has a positive trend, increasing steadily, in the period of our study there was only a decrease of six times than it should always increase every month. from January 2019 to March 2020, which is the period before the pandemic, the increase in money supply (M2) was recorded at IDR 795,472 trillion rupiah, and during the pandemic it was IDR 756,604 trillion rupiah, so that data during our research period the money supply (M2) had an increase of IDR 1,349.886 trillion rupiah or $23.9 \%$, so it can be said that the money supply always has an upward trend from time to time, both before the pandemic and during the pandemic (Marzuki et al., 2021). 


\section{Results and Discussions}

1. Results

1) Model Testing

\begin{tabular}{ccccccc}
\hline \multirow{2}{*}{ Indicators } & \multicolumn{3}{c}{ before pandemic } & \multicolumn{3}{c}{ during pandemic } \\
\cline { 2 - 7 } & $\Delta \mathbf{P 2 P}$ & $\mathbf{\Delta M 2}$ & $\mathbf{I N F}$ & $\Delta \mathbf{P 2 P}$ & $\Delta \mathbf{M 2}$ & INF \\
\hline VIF & 1 & 1.553 & 1.553 & 1.158 & 1.189 & 1.229 \\
\hline Glejser test (sig.) & 0.411 & 0.995 & 0.644 & 0.561 & 0.629 & 0.5 \\
\hline DW & & 1.734 & & 1.599 & \\
\hline ANOVA (sig.) & 0.000 & & 0.000 & \\
\hline
\end{tabular}

Source : researcher analysis

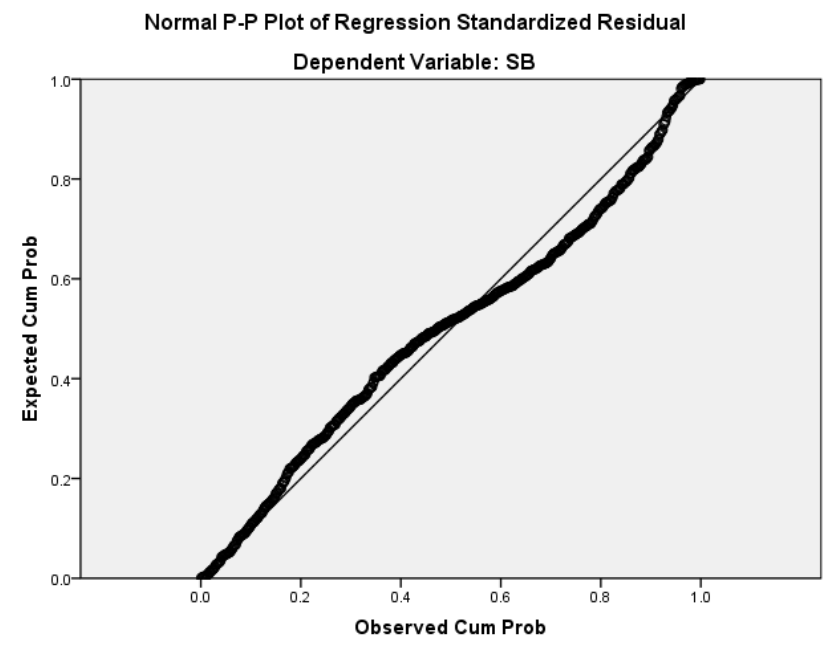

Picture 1

P-P Plot for before pandemic

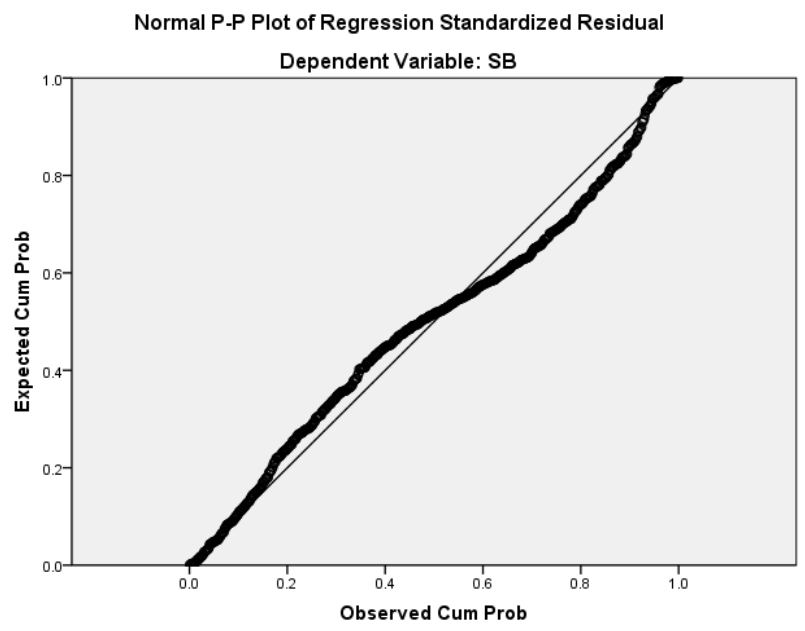

Source: researcher analysis 
From table 3 and picture 1 and 2 above, we can conclude that both multiple models for before and after pandemic are fit to use in the study.

\section{2) Research results}

Table 4

Panel data regression test results

\begin{tabular}{lcccc}
\hline \multirow{2}{*}{ Indicators } & \multicolumn{2}{c}{ before pandemic (t-1) } & \multicolumn{2}{c}{ during pandemic (t) } \\
\cline { 2 - 5 } & $\boldsymbol{\beta}$ & sig. & $\boldsymbol{\beta}$ & sig. \\
\hline constant & 0.245 & 0.434 & -0.163 & 0.146 \\
\hline $\boldsymbol{\Delta P 2 P}$ & 0.024 & 0.464 & 0.053 & 0.000 \\
\hline $\mathbf{M M 2}$ & 0.663 & 0.000 & 0.053 & 0.271 \\
\hline $\mathbf{I N F}$ & -0.626 & 0.167 & -0.213 & 0.706 \\
\hline $\mathbf{R}$ Square & 0.066 & & & 0.027 \\
\hline
\end{tabular}

Source: researcher analysis

Our analysis, as summarized by table 4, showed that P2P loans growth did not have a significant effect on small bank loans growth before the pandemic, with the coefficient of P2P showing a positive relationship with small banks. Instead, money supply growth was found to be the only variable to have a significant impact on small bank loans growth. However, analysis during the pandemic showed different results that P2P loans growth had a significant effect on small bank loans growth with both money supply and inflation having no significant effect on small bank loans. Coefficient of P2P also showed a positive direction for the growth of small bank loans.

Lastly, by comparing the beta of $\mathrm{P} 2 \mathrm{P}$ loans growth before and during the pandemic, we could prove that there is a significant difference of effect of P2P lending on small bank loans between before and during the pandemic. The effect of P2P on small bank loans is much higher during the pandemic than before the pandemic.

\section{Conclusion}

Our study focuses on how the growth of P2P Lending affecting the growth of 56 small banks loans in BUKU 1 and BUKU 2, using the panel data multiple linear regression model from the period before the covid-19 pandemic to during the covid-19 pandemic, or from January 2019 to May 2021. We found that before P2P Lending did not have a significant effect on small banks. However, during covid-19 pandemic, P2P has a significant positive effect on small bank loans. Based on the analysis, we conclude that $\mathrm{P} 2 \mathrm{P}$ lending in Indonesia works as a complement to small banks loans.Instead of having a competitive relationship, currently P2P in Indonesia can coexist with the bank.Although currently not negatively affected, small banks should 
take advantages from the development of P2P Lending. They must develop their conventional business towards digitalization, so that they will have a strong competitive power to continue to coexist with $\mathrm{P} 2 \mathrm{P}$.

The methodological choices were limited by the use of secondary data that we have no control over the collection process. Beside that, a pandemic is still ongoing. With the availability of vaccines, introduction of new covid-19 variants, or loosened up covid-19 restriction for the coming months, there could still be a lot of changes happening that could bring new dynamics in the relationship of $\mathrm{P} 2 \mathrm{P}$ and small banks.

Future research can focus on the effect of $\mathrm{P} 2 \mathrm{P}$ on financial inclusion in the country. Researching the consumer behavior toward P2P and small banks using primary data can be done to confirm our findings in this study. Finally, they can also address the impact of P2P on loans distributed by other Financial Institutions such as rural banks or cooperatives. 


\section{BIBLIOGRAFI}

Andini, G. (2017). Faktor-faktor yang menentukan keputusan pemberian kredit usaha mikro kecil dan menengah (UMKM) pada lembaga keuangan mikro peer to peer lending. Jakarta: Fakultas Ekonomi dan Bisnis UIN Syarif Hidayatullah Jakarta.Google Scholar

Firdaus, A. H., Listiyanto, E., Talattov, A. P. G., \& Taufikurahman, M. R. (2020). Kajian Tengah Tahun INDEF 2020: Menata Arsitektur Ekonomi Pasca Pandemi. INDEF. Google Scholar

Herdinata, C., \& Kohardinata, C. (2019). Pengaruh Regulasi dan Kolaborasi Terhadap Literasi Keuangan dalam Upaya Penerapan Financial Technology pada Usaha Kecil dan Menengah. Business and Finance Journal, 4(2), 135-140. Google Scholar

Keuangan, O. J. (2016). Statistik perbankan syariah. Komposisi Pembiayaan Yang Diberikan BPRS Di Indonesia. Google Scholar

Lens, R., (2016). Peer-to-Peer Lending : Opportuntites and Risks, European JOurnal of Risk Regualtion 7(4):688-700. Google Scholar

Marzuki, I., Bachtiar, E., Zuhriyatun, F., Purba, A. M. V., Kurniasih, H., Purba, D. H., Chamidah, D., Jamaludin, J., Purba, B., \& Puspita, R. (2021). COVID-19: Seribu Satu Wajah. Yayasan Kita Menulis. Google Scholar

Omarini, A., (2018), Peer-to-Peer Lending: Business Model Analysis and the Platform Dilemma, International Journal of Finance, Economics and Trade. Google Scholar

Phillipon, T., (2017). The Fintech Opportunity, Bank International of Settlement, Working Paper N0 655.

Rahayu, R., Day, J. (2017) E-commerce adoption by SMEs in developing countries: evidence from Indonesia. Eurasian Bus Rev 7, 25-41 (2017). Google Scholar

Song, Chen, Zhou and Wu, (2018), Performance of P2P Lending in China, Sustainability 10, 2987; doi : 10.3390/su10092987. Google Scholar

Suryono, R. R., Purwandari, B., \& Budi, I. (2019). Peer to peer (P2P) lending problems and potential solutions: A systematic literature review. Procedia Computer Science, 161, 204-214. Google Scholar

Tripathi, M., Maskara, P., Rangan, V. S., Mohindra, S., De Salles, A. A. F., \& Kumar, N. (2021). Radiosurgical corpus callosotomy: a review of literature. World Neurosurgery, 145, 323-333. Google Scholar

Yudaruddin, R. (2010). Do Financial Technology Startups Disturb Bank Performance?: New Empirical Evidence From Indonesian Banking. Faculty of Economics and Business Mulawarman University. Google Scholar 
Dewi Tamara, Asnan Furinto, Andreas Hakim, Djury Santosa

Zhang, Z., Hu, W., \& Chang, T. (2019). Nonlinear effects of P2P lending on bank loans in a Panel Smooth Transition Regression model. International Review of Economics \& Finance, 59, 468-473. Google Scholar

\section{Copyright holder:}

Dewi Tamara, Asnan Furinto, Andreas Hakim, Djury Santosa (2021)

First publication right:

Syntax Idea

This article is licensed under:

(c) (i) (?) 